\title{
VALIDASI DAN IMPLEMENTASI MODEL-MODEL STUDENT CENTERED LEARNING UNTUK MENINGKATKAN PENALARAN DAN KARAKTER SISWA SEKOLAH MENENGAH ATAS
}

\author{
I Wayan Santyasa ${ }^{1}$, I Wayan Sukra Warphala ${ }^{2}$, I Made Tegeh ${ }^{3}$ \\ 1,2,3 Jurusan Teknologi Pembelajaran \\ Program Pascasarjana Universitas Pendidikan Ganesha
Email : santyasa@yahoo.com, yan.sukra@yahoo.co.uk, imadetegehderane@yahoo.com

\begin{abstract}
Abstrak
Penelitian ini bertujuan mendeskripsikan tanggapan ahli isi, media, desain, dan penilaian guru terhadap model-model student centered learning (SCL) dan pedoman guru, dan dampak implementasinya untuk meningkatkan penalaran dan karakter siswa SMA. Model-model SCL yang dikembangkan, adalah (1) conceptual chagne model (CCM), (2) problem-based learning (PBL), (3) project-based learning (PjBL), (4), nature of science (NOS), (5) group investigation (Gl), dan (6) self regulated learning (SRL). Metode yang digunakan adalah research and development $(\mathrm{R} \& \mathrm{D})$. Subyek penelitian adalah 2 orang ahli, 40 orang guru, dan 314 orang siswa SMA. Instrumen penelitian terdiri dari angket untuk uji ahli dan guru, tesdan angket untuk uji kelas (siswa). Data dianalisis secara deskriptif dan statistik uji kesamaan nilai rata-rata antara sebelum dan setelah implementasi model-model SCL. Hasil penelitian menunjukkan bahwa (1) ahli isi, ahli media, dan ahli desain secara berturut-turut memberikan tanggapannya dengan kategori sesuai, sesuai, dan sangat baik. 2) Guru memberikan penilaiannya dengan kategori sangat baik dan baik. (3) Skor-skor pascates penalaran siswa secara signifikan lebih tinggi dibandingkan dengan skor-skor prates.(4) Setelah implementasi, kualitas penalaran siswa bergerak dari kategori cukup,baik, dan sangat baik, sedangkan karakter siswa berkategori cukup dan baik. Jadi, modelmodel SCL telah memenuhi kriteria pengembangan dan dapat meningkatkan penalaran dan karakter siswa SMA.
\end{abstract}

Kata kunci: student, centered, learning

\begin{abstract}
The purposes of this study were to describe the responses of content, media, designexperts, and teachers assessment on the student centered learning (SCL) models, and their implementation impacts for improving SMA students' reasoning and character. The models consisted of (1) conceptual change model (CCM), (2) problem-based learning ( $\mathrm{PBL})$, (3) project-based learning $(\mathrm{Pj} \mathrm{BL})$, (4) nature of science (NOS), (5) group investigation (GI), dan(6) self regulated learning. This
\end{abstract}


study usedresearch and development (R\&D) method. The subject of the research were 2 experts, 40 teachers, and 314 SMA students. The instruments consisted ofquestionnairefor experts and teachers, test and questionnaire forclass testing (students). To analyse the data, descriptiveand statisticttesting were used. Statistict method used to testthe equivalence of mean of thestudents' reasoning before and afterimplementingthe SCL model. The results of the study showed that (1) the response of the content, media, and design experts wereappropriate,appropriate, and very good respectively. (2) The teachers assessment were good. (3) Scors ofthe posttestof the students' reasoning significantlyhigher than the scorsof the pre test. (4) After implementasion, the qualities of the students' reasoning moves fromenough, good, tovery good chategories, but the students' character from enough to good. So, the SCL models have fulfilled the developmental criteria and be able to improve the students' reasoning and as well as their character.

Keywords: student, centered, learning

\section{PENDAHULUAN}

Dua makna esensial yang tersirat dalam UU Sisdiknas No 20 Tahun 2003, Bab II Pasal 3, bahwa (1) Pendidikan Nasional berfungsi dan bertujuan membangun karakter bangsa, dan (2) Pendidikan Nasional bertujuan membangun penalaran peserta didik. Penalaran dan karakter siswa adalah 2 (dua) variabel yang sangat penting yang seharusnya selalu dapat diupayakan pengembangannya dalam praksis pendidikan untuk menghasilkan kualitas sumber daya manusia yang lebih baik dalam rangka mendukung tujuan-tujuan pendidikan nasional.

Kenyataan yang terjadi dalam praksis pendidikan, bahwa penalaran dan karakter siswa masih sangat perlu untuk ditingkatkan. Hasil penelitian Santyasa et al (2012) menunjukan bahwa, penalaran dan karakter siswa masih berada pada kategori kurang. Selanjutnya Santyasa et al (2012) menyatakan bahwa rendahnya penalaran dan karakter siswa disebabkan karena model-model pembelajaran yang diterapkan di sekolah belum mampu memberdayakan potensi diri peserta didik secara optimal.
Mereka menemukan bahwa modelmodel pembelajaran yang cerderung diterapkan oleh guru dalam pembelajaran adalah (1) model pemberian informasi oleh guru kepada siswa, (2) model ceramah klasikal, (3) model ceramah diikuti tanya jawab, (4) model pemberian tugas rumah, (5) model demonstrasi oleh guru, (6) model penugasan siswa untuk eksperimen berdasarkan contoh guru, dan (7) model simulasi komputer yang didemonstrasikan oleh guru.Temuan ini secara tidak langsung mengindikasikan bahwa pembelajaran cenderung berpusat pada guru. Hasil-hasil penelitian sebelumnya juga secara tegas menyatakan bahwa masih terdapat berbagai permasalahan tentang proses pembelajaran yang cenderung berusat pada guru (Ardhana et al, 2005; Natajaya et al, 2008; Santyasa \& Suwindra, 2008).

Pembelajaran berpusat pada guru sering menghambat siswa dalam membagun kompetensi, baik pengetahuan maupun keterampilan, lebih-lebih dalam pengembangan nilainilai dasar untuk berpikir dan bertindak (Santyasa et al, 2012). Jika 
pembelajaran cenderung berpusat pada guru, maka pembelajaran tidak lagi menjadi ajang pembudayaan dan pemberdayaan peserta didik dalam praksis pendidikan. Dengan kata lain, agar terjadi proses pembudayaan dan pemberdayaan peserta didik, praksis pendidikan perlu berubah paradigma dari teaching menuju learning. Implikasinya, model-model pembelajaran tidak tepat lagi jika menganut paham teacher centerred, namun harus bergeser menuju student centered learning (SCL).

$$
\text { SCL sebagai ajang }
$$

pembudayaan dan pemberdayaan peserta didik merupakan salah satu cara membantu mereka untuk mengembangkan penalaran dan karakter. Schrow et al (dalam Barak \& Shakhman, 2008) menyatakan bahwa SCL dapat memberdayakan potensipotensi meta-cognition, conceptual change, self-regulation, problem solving, doing project, investigation, cooperation, inquiry on nature of sciences (NOS). Potensi-potensi tersebut terakomodasi dalam SCL. Barak dan Shakhman (2008) menyatakan bahwa SCL dapat mengembangkan kompetensi siswa, yang mencakup independent learning, problem solving, decision making, reasoning dan character development. Pernyataan tersebut mengindikasikan bahwa penerapan SCL dalam pendidikan tidak hanya bertujuan membangun penalaran siswa, namun juga potensial dalam pengembangan karakter siswa.

Pendidikan karakter sangat penting diselenggarakan sebagai upaya pengembangan kebajikan (Lichona, 1999). Yahya Khan (2010:1) menyatakan bahwa pendidikan karakter merupakan mahana untuk mangajak siswa berpikir, berprilaku, dan membuat keputusan yang dapat dipertanggung jawabkan. Raka et al (2011:xi) menyatakan bahwa pendidikan karakter diperlukan agar setiap individu menjadi orang yang lebih baik, menjadi warga masyarakat yang lebih baik, dan menjadi warga negara yang lebih baik.

Berdasarkan latar belakang di atas, tampak betapa pentingnya keberadaan SCL dalam praksis pendidikan dalam upaya mengembangkan penalaran dan karakter siswa. Oleh sebab itu, pengembangan dan validasi modelmodel SCL yang dilakukan dalam penelitian ini merupakan langkah yang strategis, tidak hanya bertujuan meningkatkan penalaran dan karakter siswa, tetapi juga merupakan salah satu cara untuk merealisasikan tujuan-tujuan pendidikan memanusiakan manusia. Dalam penelitian ini dikembangkan dan divalidasi 6 (enam) model SCL, yaitu (1) conceptual change model (CCM), (2) problem-based learning (PBL), project-based learning ( $\mathrm{PjBL})$, pembelajaran berorientasi nature of science (NOS), (5) pembelajaran kooperatif group investigation (GI), dan (6) self regulated learning (SRL).

Secara operasional, tujuan penelitian ini adalah (1) Mendeskripsikan tanggapan ahli isi, ahli media, ahli desain, dan penilaian guru terhadap model-model SCL yang telah dikembangkan, (2) mendeskripsikan keefektipan implementasi model-model SCL terhadap penalaran dan karakter siswa. 


\section{METODE}

Penelitian ini menggunakan desain Researchand Development (R\&D) (Borg\& Gall, 2005) sebagai grant design.

Penelitian ini memusatkan perhatian pada pengembangan dan validasi model-model student centered learning (SCL). Untuk memudahkan penggunaan model-model SCL tersebut, dikembangkan pula pedoman guru.

Subyek penelitian ini adalah ahli isi dan/atau media dan ahli desain berkualifikasi doktor sebanyak 2 orang, 40 orang guru dan 314 orang siswa SMA Negeri di 5 (lima) kabupaten/kota di Bali, yaitu (1) Buleleng, (2) Karangasem, (3) Klungkung, (4) Tabanan, dan (5) Jembrana.

Objek kajian dalam penelitian ini, adalah (1) tanggapan ahli isi, ahli media, ahli desain, (2) penilaian guru, dan (3) penalaran dan karakter siswa. Dimensi penalaran mengacu pada pendapat Krulik dan Rudnick (1996), yaitu (1) basic thinking, (2) critical thinking, dan (3) creative thinking. Dimensi karakter mengacu pada pandangan Suyanto (2010), yaitu (1) karakter cinta Tuhan dan segenap ciptaan-Nya, kemandirian dan tanggungjawab, (3) kejujuran/amanah, (4) diplomatis, (5) hormat dan santun, (6) dermawan, suka tolong-menolong dan gotong royong/kerjasama, (7) percaya diri dan pekerja keras, (8) kepemimpinan dan keadilan, (9) baik dan rendah hati, dan (10) karakter toleransi, kedamaian, dan kesatuan. Data tanggapan ahli dan karakter siswa dikumpulkan dengan menggunakan angket, sedangkan penalaran siswa dikumpulkan dengan tes.
Data penelitian dianalisis dengan teknik deskriptif dan uji-t. Teknik deskriptif digunakan untuk menyajikan deskripsi umum hasil penelitian, sedangkan uji- $t$ digunakan untuk menguji perbedaan nilai rata-rata antara skor-skor posttest dan skor-skor pretest. Penguji statistik dilakukan pada taraf signifikansi $5 \%$.

\section{HASIL DAN PEMBAHASAN}

Secara substantif, model-model SCL sebagai produk pengembangan mencakup komponen-komponen (1) rasional, (2) landasan teori, (3) prosedur pembelajaran, yang terdiri dari sintaks, sistem sosial yang mendukung, prinsipprinsip reaksi yang dikembangkan, sarana pendukung, dampak pembelajaran, dan dampak pengiring. Di samping komponen substansi, modelmodel SCL juga menyertakan media gambar, grafik, bagan, dan contoh terapannya dalam penyusunan rencana dan pelaksanaan pembelajaran (RPP), lembaran kerja siswa (LKS), instrumen dan rubrik penilaian, yang dalam penelitian ini hanya mencontohkan terapan pada bidang studi fisika kelas $X$ SMA. Instrumen penilaian digunakan untuk menilai proses dan produk belajar. Penilaian proses fokus untuk menilai interaksi sosial. Penilaian produk mencakup penilaian kognitif, psikomotor, dan sikap. Penilaian sikap selain mengukur sikap secara umum, juga menyertakan penilaian karakter siswa.

Desain produk pengembangan lebih memperhatikan pada komponenkomponen perwajahan, halaman judul, sekapur sirih, rasional, desain teori, prosedur pembelajaran, RPP/LKS/ Evaluasi, dan desain pedoman guru. 
Berdasarkan hasil validasi, diperoleh data hasil penilaian ahli isi, ahli media, ahli desain, dan penilaian guru terhadap semua produk modelmodel SCL. Penilaian ahli isi dan/atau media terhadap komponen-komponen rasional, landasan teori, dan prosedur pembelajaran pada keenam model SCL yang dikembangkan menunjukkan hasil sesuai dengan harapan. Ahli isi memberikan respon sesuai terhadap semua sub komponen pada semua komponen pada semua model SCL. Namun, ahli isi sebagai hasil penilaiannya juga menyertakan saran/komentar/pertimbangan dan saran perbaikan yang positip tentang konsep dan prinsip yang terdapat pada beberapa halaman pada masing-masing model SCL.
Ahli desain memberikan penilaian terhadap komponenkomponen (1) rasional, (2) kajian teori, (3) prosedur pembelajaran, (4) RPP/LKS/Evaluasi, dan (5) pedoman guru. Hasil penilaiannya berkategori sangat baik, dengan nilai rata-rata secara berturut-turut pada kelima komponen tersebut, 4,0;4,0 4,0; 4,0; dan 3,73.

Penilaian produk SCL dengan responden guru ditujukan pada 9 (sembilan) komponen, yaitu perwajahan, (2) halaman judul, (3) kata pengantar/sekapur sirih, (4) rasional, (5) kajian teori, (6) prossedur pembelajaran, (7) daftar pustaka,

RPP/LKS/Evaluasi, dan (9) buku pedoman guru. Hasil penilaian guru tersebut disajikan pada Tabel 01.

Tabel 01: Nilai rata-rata (M) dan simpangan baku (SD) serta kualifikasi komponenkomponen SCL hasil penilaian guru (masing-masing model $\mathrm{N}=5$ )

\begin{tabular}{|c|c|c|c|c|c|c|c|}
\hline \multirow[t]{2}{*}{ No } & \multirow[t]{2}{*}{ Komponen } & \multicolumn{6}{|c|}{ Nilai dan Kualifikasi Masing-Masing SCL } \\
\hline & & CCM & PBL & PjBL & NOS & GI & SRL \\
\hline 1 & Perwajahan & $\begin{array}{c}M=3,3 ; \\
S D=0,6 \text { (baik) }\end{array}$ & $\begin{array}{c}M=3,5 \\
\text { dan } \\
\mathrm{SD}=0,52 \\
\text { (sangat } \\
\text { baik) }\end{array}$ & $\begin{array}{c}M=3,5 \\
\text { dan } \\
S D=0,8 \\
\text { (sangat } \\
\text { baik) }\end{array}$ & $\begin{array}{c}\mathrm{M}=3,5 ; \\
\mathrm{SD}=0,83 \\
\text { (sangat } \\
\text { baik) }\end{array}$ & $\begin{array}{c}M=3,3 ; \\
S D=0,7 \\
\text { (baik) }\end{array}$ & $\begin{array}{l}M=3,2 ; \\
S D=0,8 \\
8 \text { (baik) }\end{array}$ \\
\hline 2 & Halaman judul & $\begin{array}{c}M=3,7 ; \\
S D=0,5 \\
\text { (sangat baik) }\end{array}$ & $\begin{array}{c}\mathrm{M}=3,6 ; \\
\mathrm{SD}=0,55 \\
\text { (sangat } \\
\text { baik) }\end{array}$ & $\begin{array}{c}\mathrm{M}=3,8 ; \\
\mathrm{SD}=0,4 \\
\text { (sangat } \\
\text { baik) }\end{array}$ & $\begin{array}{c}\mathrm{M}=3,7 ; \\
\mathrm{SD}=0,45 \\
\text { (sangat } \\
\text { baik) }\end{array}$ & $\begin{array}{c}M=3,4 ; \\
S D=0,4 \\
\text { (baik) }\end{array}$ & $\begin{array}{l}M=3,1 ; \\
S D=0,9 \\
8 \text { (baik) }\end{array}$ \\
\hline 3 & Sekapur sirih & $\begin{array}{c}M=3,0 ; \\
S D=0,4 \\
\text { (baik) }\end{array}$ & $\begin{array}{c}\mathrm{M}=3,5 ; \\
\mathrm{SD}=0,55 \\
\text { (sangat } \\
\text { baik) }\end{array}$ & $\begin{array}{c}\mathrm{M}=3,8 ; \\
\mathrm{SD}=0,4 \\
\text { (sangat } \\
\text { baik) }\end{array}$ & $\begin{array}{c}\mathrm{M}=3,8 ; \\
\mathrm{SD}=0,47 \\
\text { (sangat } \\
\text { baik) }\end{array}$ & $\begin{array}{c}M=3,5 ; \\
S D=0,55 \\
\text { (sangat } \\
\text { baik) }\end{array}$ & $\begin{array}{l}M=3,3 ; \\
S D=0,8 \\
7 \text { (baik) }\end{array}$ \\
\hline 4 & Rasioal & $\begin{array}{c}M=3,5 ; \\
S D=0,6 \\
\text { (sangat baik) }\end{array}$ & $\begin{array}{c}\mathrm{M}=3,6 ; \\
\mathrm{SD}=0,51 \\
\text { (sangat } \\
\text { baik) }\end{array}$ & $\begin{array}{c}\mathrm{M}=3,8 ; \\
\mathrm{SD}=0,4 \\
\text { (sangat } \\
\text { baik) }\end{array}$ & $\begin{array}{c}\mathrm{M}=3,6 ; \\
\mathrm{SD}=0,44 \\
\text { (sangat } \\
\text { baik) }\end{array}$ & $\begin{array}{c}M=3,4 ; \\
S D=0,6 \\
\text { (baik) }\end{array}$ & $\begin{array}{c}M=3,5 ; \\
S D=0,5 \\
8 \\
\text { (sangat } \\
\text { baik) }\end{array}$ \\
\hline 5 & Kajian teori & $M=3,5$ & $M=3,4$ & $M=3,8$ & $M=3,7$ & $M=3,1$ & $M=3,5$ \\
\hline
\end{tabular}




\begin{tabular}{|c|c|c|c|c|c|c|c|}
\hline & & $\begin{array}{c}\mathrm{SD}=0,5 \\
\text { (sangat baik) }\end{array}$ & $\begin{array}{c}\mathrm{SD}=0,6 \\
\text { (baik) }\end{array}$ & $\begin{array}{c}\mathrm{SD}=0,3 \\
\text { (sangat } \\
\text { baik) }\end{array}$ & $\begin{array}{c}\mathrm{SD}=0,5 \\
\text { (sangat } \\
\text { baik) }\end{array}$ & $\begin{array}{c}\mathrm{SD}=0,64 \\
\text { (baik) }\end{array}$ & $\begin{array}{c}\mathrm{SD}=0,5 \\
8 \\
\text { (sangat } \\
\text { baik) }\end{array}$ \\
\hline 6 & $\begin{array}{l}\text { Prosedur } \\
\text { pembelajaran }\end{array}$ & $\begin{array}{c}M=3,4 ; \\
S D=0,5 \\
\text { (baik) }\end{array}$ & $\begin{array}{c}\mathrm{M}=3,5 ; \\
\mathrm{SD}=0,55 \\
\text { (sangat } \\
\text { baik) }\end{array}$ & $\begin{array}{c}\mathrm{M}=3,9 ; \\
\mathrm{SD}=0,3 \\
\text { (sangat } \\
\text { baik) }\end{array}$ & $\begin{array}{c}\mathrm{M}=3,8 ; \\
\mathrm{SD}=0,45 \\
\text { (sangat } \\
\text { baik) }\end{array}$ & $\begin{array}{c}M=3,5 ; \\
S D=1,1 \\
\text { (sangat } \\
\text { baik) }\end{array}$ & $\begin{array}{c}\mathrm{M}=3,5 ; \\
\mathrm{SD}=0,5 \\
3 \\
\text { (sangat } \\
\text { baik) }\end{array}$ \\
\hline 7 & Daftar pustaka & $\begin{array}{c}M=3,7 ; \\
S D=0,5 \\
\text { (sangat baik) }\end{array}$ & $\begin{array}{c}\mathrm{M}=3,8 ; \\
\mathrm{SD}=0,47 \\
\text { (sangat } \\
\text { baik) }\end{array}$ & $\begin{array}{c}\mathrm{M}=3,9 ; \\
\mathrm{SD}=0,3 \\
\text { (sangat } \\
\text { baik) }\end{array}$ & $\begin{array}{c}\mathrm{M}=3,9 ; \\
\mathrm{SD}=0,11 \\
\text { (sangat } \\
\text { baik) }\end{array}$ & $\begin{array}{c}\mathrm{M}=3,7 ; \\
\mathrm{SD}=0,5 \\
\text { (sangat } \\
\text { baik) }\end{array}$ & $\begin{array}{l}M=3,4 ; \\
S D=0,6 \\
4 \text { (baik) }\end{array}$ \\
\hline 8 & $\begin{array}{l}\text { RPP/LKS/ } \\
\text { Evaluasi }\end{array}$ & $\begin{array}{c}\mathrm{M}=3,7 \\
\mathrm{SD}=0,4 \\
\text { (sangat baik) }\end{array}$ & $\begin{array}{c}\mathrm{M}=3,5 \\
\mathrm{SD}=0,59 \\
\text { (sangat } \\
\text { baik) }\end{array}$ & $\begin{array}{c}\mathrm{M}=3,9 ; \\
\mathrm{SD}=0,3 \\
\text { (sangat } \\
\text { baik) }\end{array}$ & $\begin{array}{c}\mathrm{M}=3,8 \\
\mathrm{SD}=0,3 \\
\text { (sangat } \\
\text { baik) }\end{array}$ & $\begin{array}{c}\mathrm{M}=3,6 ; \\
\mathrm{SD}=0,5 \\
\text { (sangat } \\
\text { baik) }\end{array}$ & $\begin{array}{c}M=3,4 ; \\
S D=0,6 \\
\text { (baik) }\end{array}$ \\
\hline 9 & $\begin{array}{l}\text { Buku } \\
\text { pedoman guru }\end{array}$ & $\begin{array}{c}M=3,6 ; \\
S D=0,55 \\
\text { (sangat baik) }\end{array}$ & $\begin{array}{c}M=3,4 ; \\
S D=0,66 \\
\text { (baik) }\end{array}$ & $\begin{array}{c}\mathrm{M}=3,8 ; \\
\mathrm{SD}=0,43 \\
\text { (sangat } \\
\text { baik) }\end{array}$ & $\begin{array}{c}\mathrm{M}=3,5 ; \\
\mathrm{SD}=0,54 \\
\text { (sangat } \\
\text { baik) }\end{array}$ & $\begin{array}{c}\mathrm{M}=3,5 ; \\
\mathrm{SD}=0,53 \\
\text { (sangat } \\
\text { baik) }\end{array}$ & $\begin{array}{l}M=3,4 ; \\
S D=0,7 \\
1 \text { (baik) }\end{array}$ \\
\hline & $\begin{array}{r}\text { Rata-Rata dan } \\
\text { kualifikasi }\end{array}$ & $\begin{array}{c}M=3,5 ; \\
\text { SD=0,52 } \\
\text { (sangat } \\
\text { baik) }\end{array}$ & $\begin{array}{c}M=3,5 ; \\
\text { SD=0,56 } \\
\text { (sangat } \\
\text { baik) }\end{array}$ & $\begin{array}{c}M=3,8 ; \\
S D=0,4 \\
\text { (sangat } \\
\text { baik) }\end{array}$ & $\begin{array}{c}M=3,7 ; \\
\text { SD=0,45 } \\
\text { (sangat } \\
\text { baik) }\end{array}$ & $\begin{array}{c}M=3,4 ; \\
S D=0,61 \\
\text { (baik) }\end{array}$ & $\begin{array}{l}M=3,4 ; \\
S D=0,7 \\
1 \text { (baik) }\end{array}$ \\
\hline
\end{tabular}

Keterangan: $\mathrm{SCL}=$ student centered learning, $\mathrm{CCM}=$ conceptual change model, $\mathrm{PBL}$ $=$ problem-based learning, $\mathrm{PjBL}=$ project-based learning, NOS = Nature Of Science, $\mathrm{Gl}=$ group investigation, $\mathrm{SRL}=$ self regulated learning, Nilai 1 = sangat kurang, $2=$ kurang, 3 = baik, 4 = sangat baik

Berdasarkan Tabel 01, tampak bahwa kualitas respon guru terhadap produk model-model SCL adalah dengan kategori-kategori sangat baik untuk model-model CCM, PBL, PjBL, NOS, dan baik untuk model-model GI dan SRL.
Hasil implementasi model-model SCL dalam pembelajaran fisika di kelas menunjukkan dampak pembelajaran seperti yang ditunjukkan pada Tabel 02 dan Tabel 03.

Tabel 02: Nilai Rata-Rata (M) dan Simpangan Baku (SD) penalaran pada semua pasangan SCL-Penalaran

\begin{tabular}{|c|c|c|c|c|c|c|c|}
\hline \multirow[t]{2}{*}{ NO } & \multicolumn{2}{|l|}{ SUMBER } & \multirow[t]{2}{*}{ M } & \multirow[t]{2}{*}{$\mathbf{N}$} & \multirow[t]{2}{*}{ SD } & \multirow[t]{2}{*}{ SEM } & \multirow{2}{*}{$\begin{array}{l}\text { KUALIFI- } \\
\text { KASI }\end{array}$} \\
\hline & SCL-OP & PAIR & & & & & \\
\hline \multirow[t]{2}{*}{1} & CCM-PK & posttest1 & 86,83 & 24 & 6,79 & 1,39 & $\begin{array}{l}\text { Sangat } \\
\text { baik }\end{array}$ \\
\hline & & pretest1 & 54,79 & 24 & 11,18 & 2,28 & Cukup \\
\hline 2 & PjBL-PK & posttest2 & 80,96 & 39 & 4,12 & 0,66 & Baik \\
\hline
\end{tabular}




\begin{tabular}{|c|c|c|c|c|c|c|c|}
\hline & & pretest2 & 42,95 & 39 & 4,93 & 0,79 & Kurang \\
\hline \multirow[t]{2}{*}{3} & \multirow[t]{2}{*}{ Gl-PK } & posttest3 & 60,11 & 28 & 6,64 & 1,25 & Cukup \\
\hline & & pretest3 & 38,11 & 28 & 4,65 & 0,88 & $\begin{array}{l}\text { Sangat } \\
\text { kurang }\end{array}$ \\
\hline \multirow[t]{2}{*}{4} & \multirow[t]{2}{*}{ PBL-KRITIS } & posttest4 & 69,51 & 43 & 11,53 & 1,76 & Cukup \\
\hline & & pretest4 & 38,47 & 43 & 13,73 & 2,09 & $\begin{array}{l}\text { Sangat } \\
\text { kurang }\end{array}$ \\
\hline \multirow[t]{2}{*}{5} & \multirow[t]{2}{*}{ PBL-KRITIS } & posttest5 & 77,59 & 27 & 10,38 & 1,99 & Baik \\
\hline & & pretest5 & 30,52 & 27 & 20,33 & 3,91 & $\begin{array}{l}\text { Sangat } \\
\text { kurang }\end{array}$ \\
\hline \multirow[t]{2}{*}{6} & \multirow[t]{2}{*}{ PjBL-KRITIS } & posttest6 & 51,26 & 35 & 7,94 & 1,34 & Kurang \\
\hline & & pretest6 & 29,29 & 35 & 6,66 & 1,13 & $\begin{array}{l}\text { Sangat } \\
\text { kurang }\end{array}$ \\
\hline \multirow[t]{2}{*}{7} & \multirow[t]{2}{*}{ GI-KRITIS } & posttest7 & 82,85 & 27 & 7,53 & 1,45 & Baik \\
\hline & & pretest7 & 36,63 & 27 & 9,68 & 1,86 & $\begin{array}{l}\text { Sangat } \\
\text { kurang }\end{array}$ \\
\hline \multirow[t]{2}{*}{8} & \multirow[t]{2}{*}{ CCM-KREATIF } & posttest8 & 85,63 & 32 & 12,44 & 2,19 & $\begin{array}{l}\text { Sangat } \\
\text { baik }\end{array}$ \\
\hline & & pretest8 & 29,84 & 32 & 13,30 & 2,35 & $\begin{array}{l}\text { Sangat } \\
\text { kurang }\end{array}$ \\
\hline \multirow[t]{2}{*}{9} & \multirow[t]{2}{*}{ NOS-KREATIF } & posttest9 & 68,57 & 30 & 14,20 & 2,59 & Cukup \\
\hline & & pretest9 & 35,83 & 30 & 8,09 & 1,48 & $\begin{array}{l}\text { Sangat } \\
\text { kurang }\end{array}$ \\
\hline \multirow[t]{2}{*}{10} & \multirow[t]{2}{*}{ SRL-KREATIF } & posttest10 & 64,78 & 29 & 10,13 & 1,88 & Cukup \\
\hline & & pretest10 & 41,87 & 29 & 7,26 & 1,35 & Kurang \\
\hline
\end{tabular}

Keterangan: CCM-PK = conceptual change model untuk mencapai pemahaman konsep, PjBL-PK = project-based learning untuk pencapaian pemahaman konsep, GI$\mathrm{PK}=$ group investigation untuk pencapaian pemahaman konsep, $\mathrm{PBL}-\mathrm{Kritis}=$ problembased learning untuk pencapaian kemampuan berpikir kritis, PjBL-Kritis = projectbased learning untuk pencapaian kemampuan berpikir kritis,Gl-Kritis = group investigation untuk pencapaian kemampuan berpikir kritis, CCM-Kreatif = conceptual change model untuk pencapaian kemampuan berpikir kreatif, NOS-Kreatif = Nature Of Science untuk pencapaian kemampuan berpikir kreatif, SRL-Kreatif = self regulated learning untuk pencapaian kemampuan berpikir kreatif, $\mathrm{SCL}=$ student centered learning, OP = obyek penalaran

Tabel 02 menunjukkan bahwa secara kualitatif penalaran siswa sebelum implementasi model-model SCL cenderung berkategori sangat

kurang, sedangkan setelah implementasi model-model SCL, penalaran siswa cenderung berkategori baik. 
Tabel 03: Hasil uji beda pasangan nilai rata-rata posttest-pretest penalaran

\begin{tabular}{|c|c|c|c|c|c|c|c|c|c|}
\hline \multirow{3}{*}{\multicolumn{2}{|c|}{ PAIR MEAN }} & \multicolumn{5}{|c|}{ Paired Differences } & \multirow[t]{3}{*}{$\mathbf{t}$} & \multirow[t]{3}{*}{ df } & \multirow{3}{*}{$\begin{array}{l}\text { Sig. (2- } \\
\text { tailed) }\end{array}$} \\
\hline & & \multirow[t]{2}{*}{$\mathbf{M}$} & \multirow[t]{2}{*}{ SD } & \multirow[t]{2}{*}{$\begin{array}{c}\text { SE } \\
\text { Mean }\end{array}$} & \multicolumn{2}{|c|}{$\begin{array}{l}95 \% \text { Confidence } \\
\text { Interval of the } \\
\text { Difference }\end{array}$} & & & \\
\hline & & & & & Lower & Upper & & & \\
\hline CCM-PK & $\begin{array}{l}\text { posttest } \\
1- \\
\text { pretest } \\
1\end{array}$ & $\begin{array}{c}32,0 \\
4\end{array}$ & 7,09 & 1,45 & 29,05 & 35,04 & 22,13 & 23 & 0,000 \\
\hline PjBL-PK & $\begin{array}{l}\text { posttest } \\
2- \\
\text { pretest } \\
2\end{array}$ & $\begin{array}{c}38,0 \\
1\end{array}$ & 5,85 & 0,94 & 36,12 & 39,91 & 40,55 & 38 & 0,000 \\
\hline Gl-PK & $\begin{array}{l}\text { posttest } \\
3- \\
\text { pretest } \\
3\end{array}$ & $\begin{array}{c}22,0 \\
0\end{array}$ & 7,49 & 1,42 & 19,09 & 24,90 & 15,55 & 27 & 0,000 \\
\hline PBL-Kritis & $\begin{array}{l}\text { posttest } \\
4 \text { - } \\
\text { pretest } \\
4\end{array}$ & $\begin{array}{c}31,0 \\
5\end{array}$ & 13,07 & 1,99 & 27,02 & 35,07 & 15,58 & 42 & 0,000 \\
\hline PBL-Kritis & $\begin{array}{l}\text { posttest } \\
5- \\
\text { pretest } \\
5 \\
\end{array}$ & $\begin{array}{c}47,0 \\
7\end{array}$ & 14,92 & 2,87 & 41,17 & 52,98 & 16,39 & 26 & 0,000 \\
\hline PBL-Kritis & $\begin{array}{l}\text { posttest } \\
6- \\
\text { pretest } \\
6 \\
\end{array}$ & $\begin{array}{c}21,9 \\
7\end{array}$ & 5,57 & 0,94 & 20,06 & 23,88 & 23,34 & 34 & 0,000 \\
\hline Gl-Kritis & $\begin{array}{l}\text { posttest } \\
7- \\
\text { pretest } \\
7\end{array}$ & $\begin{array}{c}46,2 \\
2\end{array}$ & 6,97 & 1,34 & 43,47 & 48,98 & 34,47 & 26 & 0,000 \\
\hline $\begin{array}{l}\text { CCM- } \\
\text { Kreatif }\end{array}$ & $\begin{array}{l}\text { posttest } \\
8- \\
\text { pretest } \\
8\end{array}$ & $\begin{array}{c}55,7 \\
8\end{array}$ & 13,96 & 2,47 & 50,75 & 60,82 & 22,60 & 31 & 0,000 \\
\hline $\begin{array}{l}\text { NOS- } \\
\text { Kreatif }\end{array}$ & $\begin{array}{l}\text { posttest } \\
9- \\
\text { pretest } \\
9\end{array}$ & $\begin{array}{c}32,7 \\
3\end{array}$ & 14,38 & 2,62 & 27,37 & 38,11 & 12,47 & 29 & 0,000 \\
\hline $\begin{array}{l}\text { SRL- } \\
\text { Kreatif }\end{array}$ & $\begin{array}{l}\text { posttest } \\
10- \\
\text { pretest } \\
10\end{array}$ & $\begin{array}{c}22,9 \\
0\end{array}$ & 10,21 & 1,89 & 19,02 & 26,79 & 12,08 & 28 & 0,000 \\
\hline
\end{tabular}

Keterangan: CCM-PK = conceptual change model untuk mencapai pemahaman konsep, PjBL-PK = project-based learning untuk pencapaian pemahaman konsep, GI- 
$\mathrm{PK}$ = group investigation untuk pencapaian pemahaman konsep, $\mathrm{PBL}-\mathrm{Kritis}=$ problembased learning untuk pencapaian kemampuan berpikir kritis, PjBL-Kritis = projectbased learning untuk pencapaian kemampuan berpikir kritis,Gl-Kritis = group investigation untuk pencapaian kemampuan berpikir kritis, CCM-Kreatif = conceptual change model untuk pencapaian kemampuan berpikir kreatif, NOS-Kreatif = Nature Of Science untuk pencapaian kemampuan berpikir kreatif, SRL-Kreatif = self regulated learning untuk pencapaian kemampuan berpikir kreatif.

Berdasarkan Tabel 03, tampak bahwa nilai-nilai statistik $t$ pada semua pasangan nilai rata-rata posttest dan pretest pada masing-masing perlakuan menunjukkan angka-angka signifikansi yang lebih kecil dari 0,05 . Oleh sebab itu, hipotesis nol yang menyatakan "tidak terdapat perbedaan antara skorskor posttest dan skor-skor pretest penalaran siswa", ditolak. Dengan kata lain, bahwa "terdapat perbedaan secara signifikan antara skor-skor posttest dan skor-skor pretest penalaran siswa". Jika dilihat sebaran data nilai rata-rata dan simpangan baku pada Tabel 02, tampak bahwa skor-skor posttest penalaran lebih tinggi dibandigkan dengan skorskor pretest, sehingga dapat ditarik makna bahwa implementasi modelmodel SCL dalam pembelajaran dapat meningkatkan penalaran siswa.

Hasil implementasi model-model SCL dalam pembelajaran fisika tidak hanya memberikan dampak pembelajaran, tetapi juga dampak pengiring. Dampak pengiring tersebut disajikan pada Tabel 04.

Tabel 04: Nilai rata-rata (M) dan simpangan baku karakter siswa

\begin{tabular}{|c|l|c|c|c|c|}
\hline NO & \multicolumn{1}{|c|}{ SUMBER } & N & M & SD & KUALIFIKASI \\
\hline 1 & CCM-PK & 24 & 187,00 & 19,54 & Baik \\
\hline 2 & PjBL-PK & 39 & 179,80 & 20,77 & Baik \\
\hline 3 & Gl-PK & 28 & 160,60 & 23,63 & Cukup \\
\hline 4 & PBL-KRITIS1 & 43 & 156,00 & 12,28 & Cukup \\
\hline 5 & PBL-KRITIS2 & 27 & 159,70 & 21,59 & Cukup \\
\hline 6 & PjBL-KRITIS & 35 & 178,45 & 15,56 & Baik \\
\hline 7 & GI-KRITIS & 27 & 194,50 & 10,60 & Baik \\
\hline 8 & CCM-KREATIF & 32 & 145,70 & 15,51 & Cukup \\
\hline 9 & NOS-KREATIF & 30 & 177,30 & 12,84 & Baik \\
\hline 10 & SRL-KREATIF & 29 & 172,20 & 25,13 & Cukup \\
\hline
\end{tabular}

Keterangan: $\mathrm{CCM}-\mathrm{PK}=$ conceptual change model untuk mencapai pemahaman konsep, PjBL-PK = project-based learning untuk pencapaian pemahaman konsep, GI$\mathrm{PK}$ = group investigation untuk pencapaian pemahaman konsep, $\mathrm{PBL}-\mathrm{Kritis}=$ problembased learning untuk pencapaian kemampuan berpikir kritis, PjBL-Kritis = projectbased learning untuk pencapaian kemampuan berpikir kritis,Gl-Kritis = group investigation untuk pencapaian kemampuan berpikir kritis, CCM-Kreatif = conceptual change model untuk pencapaian kemampuan berpikir kreatif, NOS-Kreatif = Nature Of Science untuk pencapaian kemampuan berpikir kreatif, SRL-Kreatif = self regulated learning untuk pencapaian kemampuan berpikir kreatif 
Tabel 04 menyatakan bahwa secara kualitatif karakter siswa bergerak dari kualitas cukup menuju pada kualitas baik. Hal ini menunjukkan bahwa implementasi model-model SCL dapat meningkatkan karakter siswa.

\section{PEMBAHASAN}

Pengembangan penalaran dan karakter bangsa bagi setiap warga negara, termasuk peserta didik di sekolah menjadi pijakan yang kuat bagi upaya pengembangan dan validasi model-model student centered learning (SCL).

Secara teoretis, upaya pengembangan dan validasi produk SCL juga dilandasi oleh dua proposisi (Santyasa et al, 2012). Pertama, bahwa model-model SCL adalah bagian yang sangat penting untuk efesiensi dan efektivitas praksis pendidikan. Implikasinya, SCL seyogyanya selalu dijadikan obyek kajian bidang pedagogi dalam upaya peningkatan efektifitas dan produktivitas pendidikan. Kedua, bahwa pemberdayaan potensi diri siswa secara total merupakan unsur terpenting dalam belajar. Implikasinya, bahwa proses belajar mesti didukung oleh modelmodel SCL.

Di samping landasan yuridis dan teoretis di atas, pengembangan dan validasi model-model SCL ini juga didukung oleh data empiris, bahwa keberadaan dan implementasi SCL dalam praksis pendidikan masih sangat minimal (Santyasa et al, 2012). Hal ini merupakan salah satu penyebab rendahnya penalaran dan karakter siswa sebagai produk pembelajaran, termasuk penalaran dan karakter siswa dalam jenjang pendidikan SMA. Santyasa et al (2012) mengungkap bahwa penalaran siswa SMA sangat rendah dan karakter siswa masih belum optimal, bahkan cenderung berkategori buruk.

Berdasarkan landasan yuridis, teoretis, dan emperis tentang nilai strategis dan pentingnya keberadaan model-model SCL, adalah suatu keniscayaan bahwa implementasi produk SCL dalam pembelajaran seyogyanya didahului oleh proses validasi dan implementasi secara intensif.

Hasil validasi isi dan ahli media menunjukkan bahwa produk modelmodel SCL berkategori sesuai dengan standar pengembangan isi dan media pembelajaran. Sementara ahli desain menyatakan bahwa semua komponen produk model-model SCL berkategori sangat baik. Hal ini disebabkan karena pengembangan model-model SCL menggunakan metode Research and Development (R\&D)(Borg\& Gall, 2005). Prosedur pengembangan berawal dari analisis kebutuhan para pengguna, analisis secara cermat saran dan masukan para pengguna, focus group discussion secara intensif, perancangan dan pengembangan yang sistematis, yang seluruhnya dilakukan dengan prosedur ilmiah. Proses-proses tersebut dilakukan dengan harapan agar produk model-model SCL tersebut dapat diakomodasi secara positif oleh para guru. Harapan ini telah terbukti tercapai, bahwa para guru di Provinsi Bali menyatakan tanggapannya secara positif terhadap semua produk modelmodel SCL. Enam produk model-model 
SCL pertama, yaitu conceptual change model (CCM), probem-based learning $(\mathrm{PBL})$, project-based learning (PjBL), dan nature of science (NOS) dinilai sangat baik oleh para guru. Dua produk lainnya, yaitu model group investigation (Gl) dan self regulated learning (SRL) dinilai baik.

Berdasarkan tanggapan positif para ahli dan para guru terhadap modelmodel SCL yang dihasilkan dalam penelitian ini, dapat dinyatakan bahwa produk model-model SCL tersebut sangat laik digunakan sebagai fasilitas pembelajaran di SMA. Model-model SCL sebagai hasil pengembangan dalam penelitian ini memiliki beberapa kelebihan. Pertama, model-model SCL tersebut dikembangkan berdasarkan rasional yang relevan, landasan teori yang inovatif, dan prosedur pembelajaran yang operasional. Prosedur pembelajaran tidak hanya menyajikan penjelasan mengenai langkah-langkah pembelajaran, tetapi juga menyertakan deskripsi yang komprehensif mengenai prinsip reaksi, sistem sosial, perangkat pendukung, dampak pembelajaran serta dampak pengiring pembelajaran, sehingga model-model SCl ini dapat diimplementasikan secara fleksibel dalam pembelajaran di sekolah. Kedua, model-model SCL tersebut dikembangkan berdasarkan analisis kebutuhan, sehingga SCL dapat membantu guru memenuhi kebutuhan akan model-model pembelajaran inovatif sebagai fasilitas pembelajaran yang efektif dan produktif dalam rangka mengakomodasi pemecahan masalah belajar siswanya. Di samping itu, hasil penelitian ini juga menjadi salah satu ajang bagi guru dalam upaya pengembangan kompetensi pedagogi. Ketiga, model-model SCL ini dikembangkan dengan prosedur ilmiah, sehingga sebagai produk penelitian dapat diandalkan validitas dan reliabelitasnya. Keempat, model-model SCL ini cukup menarik dari segi tampilannya, sehingga memotivasi guru dalam mengimplementasikannya. Dengan demikian, secara prinsip modelmodel SCL ini laik diimplementasikan, baik dalam skup terbatas, maupun dalam skup yang lebih luas, termasuk uji keunggulannya secara komparatif dalam pembelajaran di sekolah.

Hasil implementasi model-model SCL dalam skup terbatas dalam pembelajaran fisika SMA di Kabupaten Buleleng menunjukkan bahwa modelmodel SCL dapat memberikan dampak pembelajaran yang efektif. Hal ini terbukti dari hasil uji-t, bahwa skor-skor posttest penalaran siswa dalam pembelajaran fisika secara signifikan lebih tinggi dibandingkan dengan skorskor pretest. Penalaran siswa direpresentasikan oleh akumulasi dari basic, critical, dan creative thinking. Keefektipan model-model SCL dalam pembelajaran khususnya dalam pencapaian penalaran yang terungkap dari hasil penelitian ini merupakan suatu bukti bahwa pemberdayaan potensi diri siswa dalam pembelajaran sangat menentukan proses dan hasil belajarnya. Santyasa et al (2012) menyatakan bahwa SCL menyediakan peluang pemberdayaan potensi diri siswa secara optimal untuk lebih bertanggung jawab pada proses dan hasil belajarnya. Marzano et al (1988) menyatakan bahwa, pembelajaran yang memberdayakan potensi diri peserta didik dipastikan dapat meningkatkan 
kemampuan-kemampuan berpikir mereka, tidak hanya pada level rendah, tetapi juga mencapai kemampuan berpikir tingkat tinggi. Di samping itu, Santyasa et al (2012) juga menyatakan bahwa SCL merupakan suatu wahana untuk mengembalikan siswa ke fitrahnya sebagai manusia yang berada dan mengada, yang harus tumbuh secara utuh dalam rangka mengembangkan kemanusiannya.

Secara rata-rata akumulatif, kualitas penalaran siswa sebagai dampak implementasi model-model SCL dalam pembelajaran cenderung berkategori baik. Kategori sangat baik pada level basic thinking dan creative thinking dapat dicapai dalam implementasi CCM. Fakta ini konsisten dengan hasil-hasil penelitian sebelumnya, bahwa CCM berpengaruh positif terhadap proses dan hasil-hasil belajar siswa (Santyasa et al, 2006; Santyasa \& Suwindra, 2008).

Kategori baik pada level critical thinking dicapai dalam implementasi model-model PBL dan GI. Hasil penelitian ini sesuai dengan temuantemuan sebelumnya (Nopi Aryati, 2008; Okur Akcay \& Daymus, 2012; Santyasa \& Suwindra, 2008).

Kategori cukup pada level-level basic, critical, dan creative thinking, dicapai dalam implementasi modelmodel PjBL, NOS, dan SRL. Kategori cukup merupakan kriteria keberhasilan minimal dalam implementasi SCL. Hasil implementasi ini sesuai dengan temuantemuan penelitian sebelumnya (Caliskan \& Seilcuk, 2012; Eka Saputra, 2009; Mertin, 2012; Santyasa \& Suwindra, 2009; Sutiawan, 2009).

Pembahasan terhadap temuantemuan mengenai keefektipan model- model CCM, PBL, PjBL, NOS oriented learning, Gl, dan SRL terhadap levellevel basic, critical, dan creative thinking tersebut merupakan suatu indikasi bahwa model-model SCL sebagai produk pengembangan dalam penelitian ini dapat meningkatkan penalaran bagi siswa SMA.

Implementasi model-model SCL dalam penelitian ini tidak hanya memiliki dampak pembelajaran (learning effect), yaitu meningkatnya penalaran siswa, tetapi juga memiliki dampak pengiring (nurturen effect). Dampak pengiring yang telah diukur dalam penelitian ini adalah karakter siswa. Karakter siswa yang terungkap bergerak dari kategori cukup menuju kategori baik. Karakter siswa dengan kategori cukup muncul sebagai dampak pengiring implementasi Gl dalam pencapaian pemahaman konsep, PBL dalam pencapaian berpikir kritis, CCM atau SRL dalam pencapaian berpikir kreatif. Sementara karakter siswa dengan kategori baik muncul dalam implementasi CCM dalam pencapaian pemahaman konsep, PjBL dalam pencapaian pemahaman konsep dan/atau berpikir kritis, GI dalam pencapaian berpikir kritis, dan NOS oriented learning dalam pencapaian berpikir kreatif. Temuan-temuan tersebut mengindikasikan bahwa implementasi model-model SCL dalam pembalajaran dapat meningkatkan karakter siswa. Santyasa et al (2012) menyatakan bahwa penerapan modelmodel SCL dalam pembelajaran dapat meningkatkan karakter siswa. Hal senada juga disampaikan oleh Marzano et al (1988), bahwa pembelajaran yang lebih memberdayakan potensi diri peserta didikdapat mengembangkan dimensi-dimenaikarakter yang baik bagi 
siswa, mencakup sikap dan nilai yang positif, kebiasaan berpikir positif, dan moral yang baik. Pembelajaran yang lebih memberdayakan potensi diri peserta didik terakomodasi dalam model-model SCL yang dikembangkan dalam penelitian ini. Lickona (1999),secara tegas menyatakan bahwa implementasi SCL dalam pembelajaran dapat meningkatkan karakter siswa menuju kearah yang lebih baik.

Berdasarkan pembahasan terhadap temuan-temuan penelitian ini, dapat dirumuskan proposisi-proposisi sebagi berikut. Pertama, SCL adalah landasan bagi siswa untuk melakukan olah hati, olah pikir, dan olah raga secara berkelanjutan. Implikasinya, adalah suatu keniscayaan bagi para teoretisi, praktisi, dan pemerhati pendidikan untuk selalu mencermati dan mengkritisi model-model pembelajaran dalam rumpun SCL untuk senantiasa didesain, dikembangkan, diimplementasikan, dikelola, dan dievaluasi secara berkelanjutan dalam praksis pendidikan. Kedua, SCL adalah wahana bagi peserta didik untuk melakukanbudaya dialog, belajar sepanjang hayat, belajar tentang cara, belajar untuk tahu, belajar untuk mengerjakan, belajar untuk mengenali jati diri, dan belajar untuk bisa hidup bersama di dunia nyata. Implikasinya, bahwa SCL seyogyanya menjadisalah satu alternatif cara dan sekaligus orientasi bagi praksis pendidikan dalam upaya memperbaiki kualitas sumber daya manusia ke arah yang lebih baik. Ketiga, SCL adalah wahana bagi peserta didik untuk mengenal dan memahami dirinya, mengenal rahasia alam, sekaligus mengagumi penciptanya. Implikasinya, bahwa
SCLseyogyanya dapat pengakuan sebagai salah satu perangkat pendidikan untuk memanusiakan manusia, SCL seyogyanya dijadikan ajang melakukan gerakan perubahan pola pikir dalam pengelolaan lembaga pendidikan dalam rangka mengakrabkan peserta didik terhadap pemahaman hubungan antar manusia dalam menjunjung tinggi kemanusiannya, meningkatkan kesadaran akan pentingnya hubungan manusia dengan Tuhan, dan juga dengan alam makrosmosnya.

\section{PENUTUP}

Berdasarkan temuan-temuan penelitian dan pembahasan yang telah diuraikan sebelumnya, diajukan 3 (ting) simpulan sebagai berikut. (1) Hasil validasi produk mengungkapkan bahwa model-model SCL yang telah dikembangkan dalam penelitian ini adalah laik sebagai produk pembelajaran, (2) implementasi modelmodel SCL yang telah dikembangkan dalam uji lapangan adalah efektif untuk meningkatkan penalaran siswa, dan (3) implementasi model-model SCL dalam pembelajaran adalah efektif untuk meningkatkan karakter siswa.

Model-model SCL telah memenuhi kriteria pengembangan dan dapat meningkatkan penalaran dan karakter siswa. Oleh sebab itu, dapat diajukan saran-saran kepada pemerintah, dinas pendidikan, sekolah, dan guru, (1) SCL seyogyanya dijadikan salah satu cara mendidik untuk mengembalikan siswa ke fitrahnya sebagai manusia dalam rangka meningkatkan derajat kemanusiannya, (2) SCL seyogyanya senantiasa dilatihkan kepada para guru dalam 
rangka

profesionalismenya agar mampu memberikan pelayanan humanis kepada siswa dalam meraih pengetahuan, keterampilan, dan sikap (karakter) yang lebih baik, (3) SCL seyogyanya dijadikan ajang untuk mengajak siswa melakukan proses-proses pembudayaan dan pemberdayaan diri secara optimal.

\section{DAFTAR PUSTAKA}

Ardhana, W., Kaluge, L., \& Purwanto. 2005. Pembelajaran inovatif untuk pemahaman dalam belajar matematika dan sains di SD, SLTP, dan di SMU. Laporan penelitian. Penelitian Hibah

Pasca Angkatan I tahun III. Direktoral Penelitian dan Pengabdian Pada Masyarakat. Ditjen Dikti. Depdiknas.

Barak, M. \& Shakhman, L. 2008. Reform-based science teaching: Teachers' instructional practices and conceptions. Eurasia Journal of Mathematics, Science \& Technology Eduvation. 4(1). 11-20.

http://www.ejmste.com/v4n1/eur asia v4n1 Barak.pdf.

Borg, R. W.\& Gall, M.D. 2005. Edicational reseach: An introduction. Fifth edition. Logman.

Caliscan, S. \& Seicuk, G. S. 2010. Preservice teachers' use of self regulation strategies in phyisics problem solving: Effects of gender and academic achievement. International Journal of The Physical Sciences. 5(12). 1926-1938.
Cheng, E. C. K. 2011. The role of self regulated learning in enhancing learning performance. The International Journal of Research and Review. 6(1). 1-15.

Eka Saputra, I G. 2009. Pengaruh pembelajaran berorientasi nature of science terhadap hasil belajar siswa SMA. Skripsi (Tidak diterbitkan). Undiksha.

Foss, P., Carney, N., McDonald, K., \& Rooks, M. 2007. Project-Based Learning Activities for ShortTermIntensive English Programs.Professional Teaching Articles. 23. http://www.asian-efljournal.com/pta Oct 07 ypf\&nc \&km\&mr.php

Frank, M. \& Barzilai, A. 2006. Project based learning: Instructional strategyfor developing technological literacy. Journal of Technology Education. 18(1). 39-53.

Giere, R. N. 1984. Understanding Scientific Reasoning. $2^{\text {nd }}$ Edition. New York: Holt, Rinehart and Winston.

Gunstone, R. F., Gray, C.M.R,. \& Searley, P. 1992. Some longterm effects of uninformed conceptual change. Science Education. 76(2). 175-197.

Krulik, S. \& Rudnick, J. A. 1996. The new sourcebook for teacing reasoning and problem solving in Junior and Senior High School. Boston: Allyn and Bacon.

Koesoema, D. 2007. Pendidikan karakter: Strategi mendidikanakdi zamanglobal. Jakarta: PT. Grasindo.

Lang, K. S. 2006. Effects of a cognitiveinfusion intervention on critical

Jurnal Pendidikan Indonesia |525 
thinking skills and dispositions of pre-service teachers.

http://www.aare.edu.au/

KON06852.htm.

Lewis, A. \& Smith, D. 1993. Defining higher order thinking. Dalam Donmoyer, R.\& Merryfield, M.M.(Eds): Theory into practice: Teaching for higher order thinking. 32(3). pp. 131-137.

Lickona, T. 1999. Character education: The cultivation of virtue. In Regeluth, C. M. (Ed.): Instructional design theories and model: $A$ new paradigm of instructional theory. 591-612. United States of America: Lawrence Erlboum Associates, Inc.

Marzano, R. J., Brandt, R. S., Hughes, C. S., Jones, B. F., Presseisen, B. Z., Rankin, S. C., \& Suhor, C. 1988. Dimensions of thinking: $A$ framework for curriculum and instructon. Alexandria, Virginia: Association for Supervision and Curriculum Development.

Metin, D. 2012. Effect of a science camp on the children's vews of tentative nature of science. Journal of Studies in Education. 2(1). 164-183. www.macrothink. org/ise.

Nopi Aryati, K. 2008. Pengaruh pembelajaran berbasis masalah dan gaya belajar terhadap kemampuan berpikir kritis siswa SMA. Skripsi (Tidak diterbitkan). Undiksha.

Okur Akcay, N. \& Doymus, K. 2012. The effects of group investigation and cooperative learning techniques applied in teaching force and motion subjects on students' academic achievements. Journal of Educational Sciences Research: International EJournal. 2(1). 109-123.

Rahman, M. B. B. H. A., Ismail, H. N., Daud, K. A. M., \& Jaafar, M. F. 2011. Competency based assessment (CBA) of engineering students'bproduct development via project-based learning (PjBL) process. International Journal of Business and Social Science. 2(4). 221229.

Raka, G., Mulyana, Y., Markam, S. S., Semiawan, C. R., Hasan, S. H., Bastaman, H. D., \& Nuracham, N. 2011. Pendidikan karakter di sekolah: Dari gagasan ke tindakan. Jakarta: Elex Media Komputindo.

Santyasa, I W. 2006. Pembelajaran inovatif: Model kolaboratif, basis proyek, dan orientasi NOS. Makalah. Disajikan dalam seminar di Sekolah Menengah Atas (SMA) Negeri 2 Semarapura Tanggal 27 Desember 2006, di Semarapura.

Santyasa, I W.\& Suwindra, I N P. 2008. Pengembangan pemahaman konsep dan kemampuan pemecahan masalah fisika bagis siswa SMA dengan pemberdayaan model perubahan konseptual berseting investigasi kelompok. Laporan Penelitian Fundamental Dikti. Lembaga Penelitian Undiksha.

Santyasa, I W. \& Suwindra, I N P. 2009. Penerapan pembelajaran berbasis proyek untuk meningkatkan hasil belajar mahasiswa dalam perkuliahan

Jurnal Pendidikan Indonesia |526 
semiar di Jurusan Pendidikan Fisika Undiksha. Laporan teaching grant. Undiksha.

Santyasa, I W., Sukra Warpala, I W., \& Tegeh, I M. 2012. Pengembangan model-model student centered learning untuk meningkatkan penalaran dan karakter siswa SMA. Laporan penelitian HPTP Tahun ke-1. Undiksha.

Shadiq, F. 2007. Penalaran atau reasoning: Perlu dipelajari para siswa di sekolah?http://prabu. telkom.us/2007/08/29/penalaranatau-reasoning/ penalaran atau reasoning.htm

Sudrajat, A. 2010. Konsep pendidikan karakter. http://akhmadsudrajat. wordpress.com/ 2010/09/15/ konsep-pendidikan-karakter/

Suping, S. M. 2004. Conceptual Change among Students in Science. ERIC Clearinghouse for Science Mathematics and Environmental
Education. http://www.ericdigest s. org/2004-3/change.html

Sutiawan, M. 2009. Pengaruh model self regulated learning terhadap hasil belajar siswa SMA. Skripsi (Tidak diterbitkan). Undiksha.

Suyanto. 2010. Urgensi pendidikan karakter.http://waskitamandiribk. wordpress.com/ 2010/06/02/urgensi-pendidikankarakter/Tabachnich, B. G., \& Fidell, L. S. 1983. Using multivariate statistics. Second edition. New York: Harper \& Row, Publishers.

Wenning, C. J. 2006. A pramework for teaching the nature of science. Journal of Physics Teacher Education Online. 3(3). 3-10. http://www.phy.ilstu. edu/jpteo

Yahya Khan, D. 2010. Pendidikan karakter berbasis potensi diri mendongkrak kualitas pendidikan. Yogyakarta: Pelangi. 